\title{
The association between calcium dobesilate and pancytopenia in type 2 diabetes: A case report
}

\section{Tip 2 diyabet hastasında kalsiyum dobesilat ile pansitopeni ilişkisi: Bir olgu sunumu}

\author{
Aylin Cesur ${ }^{1}$, Meltem Aylı ${ }^{2}$, Mustafa Cesur ${ }^{3}$, Sibel Ertek ${ }^{4}$ \\ 'Department of Biochemistry, Medical Faculty, Gazi University, Ankara, Turkey \\ 2Department of Hematology, Medical Faculty, Ufuk University, Ankara, Turkey \\ ${ }^{3}$ Department of Endocrinology and Metabolic Diseases, Guven Hospital, Ankara, Turkey \\ ${ }^{4}$ Department of Endocrinology and Metabolic Diseases, Medical Faculty, Ufuk University, Ankara, Turkey
}

\section{To the Editor,}

Diabetic patients with polypharmacy are prone to unexpected drug side effects. Chronic venous insufficiency (CVI) is frequent in the type 2 diabetic population due to advanced age and obesity, and is associated with increased podiatric risk [1,2]. Calcium dobesilate $(\mathrm{CaD})$ is a widely prescribed veno-tonic drug for CVI, diabetic retinopathy, and the symptoms of hemorrhoid attacks [3]. To date, all published cases of CaD-induced agranulocytosis are $>60$ years of age [4,5-10]. Ibanez et al. recently reported that $\mathrm{CaD}$ was strongly associated with the risk of agranulocytosis [10]. Herein we present a case of CaD-induced pancytopenia in an 80-yearold male diabetic patient. We had written informed consent from the patient.

The patient presented to our hospital with a fever of $39^{\circ} \mathrm{C}$. He had been type 2 diabetic for 25 years and was treated with repaglinide $2 \mathrm{mg}$ b.i.d. and insulin glargine 20U o.p.d. He was also hypertensive and dyslipidemic, and was using atenolol $50 \mathrm{mg} /$ day, lisinopril $20 \mathrm{mg} /$ day, amlodipine $10 \mathrm{mg} / \mathrm{day}$, hydrochlorothiazide $50 \mathrm{mg} /$ day, atorvastatin $10 \mathrm{mg} /$ day, and acetylsalicylic acid $100 \mathrm{mg} /$ day for last 8 years. Six weeks before he presented to hospital he was diagnosed with CVI and CaD $500 \mathrm{mg}$ b.i.d. was started following a cardiovascular surgery consultation.

After 6 weeks of the treatment leukopenia, thrombocytopenia, and anemia were observed. His hematoxylin-eosin-stained blood smear confirmed markedly decreased platelet and leucocyte counts, accompanied by normochromic normocytic red cells (Table). CaD treatment was withdrawn because of the potential side effects. On physical examination the patient did not have organomegaly or palpable lymph nodes. His iron, ferritin, vitamin B12, and folate levels, and reticulocyte count were within normal limits, and ANA (anti nuclear antibody) and anti-double stranded DNA test results were negative. The patient was hospitalized and was prescribed intravenous ceftriaxone $2 \mathrm{~g} /$ day and clarithromycin $400 \mathrm{mg} /$ day, following the diagnosis 
of pneumonia. The patient was discharged after 1 week of hospitalization with improved hemogram results (Table 1 ).

Three months after discharge he was again admitted to our hospital with a fever of $38.6^{\circ} \mathrm{C}$. It was learned that he again had started taking $\mathrm{CaD}$. Pancytopenia was diagnosed, CaD was withdrawn, and the same intravenous antibiotic therapy was started again. Bone marrow biopsy and aspiration were performed from the iliac crest. Wright staining of the bone marrow aspiration smear microscopically showed normal erythroid and myeloid cell lines. The patient was discharged with a normal blood count after 1 week.

In conclusion, we want to emphasize the potential for serious side effects that affect the immune system in polypharmacy diabetic patients, such as granulocytopenia, and the importance of pharmacovigilance in patients with chronic diseases and the risk of comorbidity.

Table 1. The patient's complete blood count during the follow-up period, with and without medication

\begin{tabular}{lcccc}
\hline & $\begin{array}{c}\text { Before } \\
\mathrm{CaD}\end{array}$ & $\begin{array}{c}\mathbf{6} \text { Weeks After } \\
\mathrm{CaD}\end{array}$ & $\begin{array}{c}\text { 1 Week After } \\
\text { Hospitalization }\end{array}$ & $\begin{array}{c}\text { 3 months later, } \\
\text { again with } \\
\mathrm{CaD} \text { use }\end{array}$ \\
\hline WBC $\left(\times 10^{9} \mathrm{~L}^{-1}\right)$ & 6.2 & 2.4 & 5.93 & 4.0 \\
\hline Neutrophils (\%) & 67 & 34 & 70 & 74 \\
\hline Lymphocytes (\%) & 20 & 48 & 21 & 16 \\
\hline Monocytes (\%) & & & & \\
\hline Basophiles (\%) & 9 & 16 & 7 & 6 \\
\hline Eosinophils (\%) & 1 & 1 & 1 & 2 \\
& 3 & 1 & 1 & 2 \\
\hline Hb (g dL-1) & 13.1 & 10.3 & 11.4 & 10.8 \\
\hline Platelet $\left(\times 10^{9} \mathrm{~L}^{-1}\right)$ & 219 & 122 & 235 & 101 \\
Platelet $\left(\times 10^{9} \mathrm{~L}^{-1}\right)$ & 219 & 122 & 235 & 101 \\
\hline
\end{tabular}

CaD: Calcium dobesilate; $\mathrm{WBC}$ : white blood cells; Hb: hemoglobin

\section{Conflict of interest statement}

None of the authors of this paper has a conflict of interest, including specific financial interests, relationships, and/or affiliations relevant to the subject matter or materials included.

\section{References}

1. Lionis C, Erevnidou K, Antonakis N, Argyriadou S, Vlachonikolis I, Katsamouris A; CVI Research Group. Chronic venous insufficiency . A common health problem in general practice. Int Angiol 2002;21:86-92.

2. Fowkes FGR, Ewans CJ, Lee AJ. Prevalance and risk factors of chronic venous insufficiency. Angiology 2001;52:S5-15. [CrossRef]

3. Allain H, Ramelet AA, Polard E, Bentue-Ferrer D. Safety of calcium dobesilate in chronic venous disease, diabetic retinopathy and haemorrhoids. Drug Saf. 2004;27:649-60. [CrossRef]

4. Zapater P, Horga JF, Garcia A. Risk of drug-induced agranulocytosis: the case of calcium dobesilate. Eur J Clin Pharmacol. 2003;58:767-72.

5. Ibanez L, Ballarin E, Vidal X, Laporte JR. Agranulocytosis associated with calcium dobesilate clinical course and risk estimation with the case-control and the casepopulation approaches. Eur J Clin Pharmacol. 2000;56:763-7.

6. Kulessa W, Becker EW, Berg PA. Recurrent agranulocytosis after taking calcium dobesilate. Dtsch Med Wochenschr. 1992;117:372-4. [CrossRef]

7. Garcia Benayas E, Garcia Diaz B, Perez G. Calcium dobesilate-induced agranulocytosis. Pharm World Sci. 1997;19:251-2. [CrossRef]

8. Azaceta G, Sáenz-Cusi A, Olave T, Palomera L. Agranulocitosis inducida por dobesilato cálcico: a propósito de un nuevo caso. An Med Interna 2000;17: 337-8.

9. Duggal L, Thukral R, Kumar S. Calcium dobesilateinduced agranulocytosis. J Assoc Physicians India. 2005;53:320-1.

10. Ibanez L, Vidal X, Ballarin E, Laporte JR. Populationbased drug-induced agranulocytosis. Arch Intern Med. 2005;165:869-74. [CrossRef] 